\title{
Long-term sealing ability of GuttaFlow versus Ah Plus using different obturation techniques
}

\author{
Aline Savariz ${ }^{1}$, María-Paloma González-Rodríguez ${ }^{2}$, Carmen-María Ferrer-Luque $^{3}$ \\ ${ }^{1}$ BDS, Graduate in Dentistry \\ ${ }^{2}$ DDS, PhD, Contracted Professor \\ ${ }^{3}$ DDS, MD, PhD, Associate Professor Department of Dental Pathology and Therapeutics, School of Dentistry, University of \\ Granada (Spain)
}

Correspondence:

Department of Dental Pathology and Therapeutics

School of Dentistry, University of Granada, Spain

Campus de Cartuja, Colegio Maximo s/n.

18071, Granada, Spain

cferrer@ugr.es

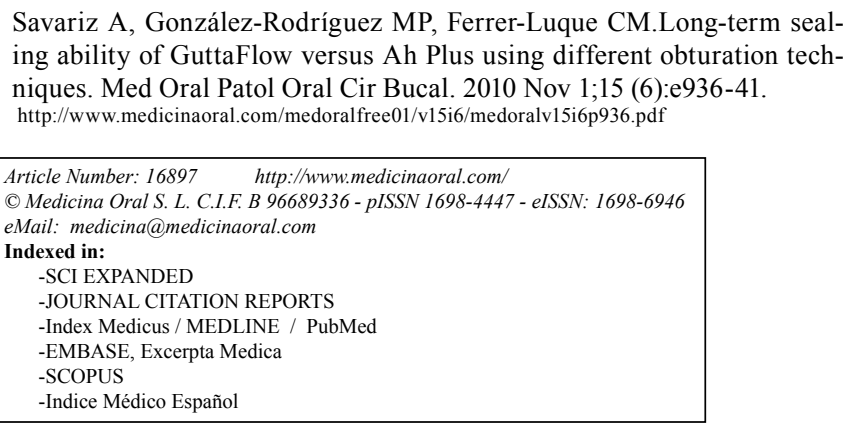

\begin{abstract}
Objective. To compare the long-term sealing ability of GuttaFlow ${ }^{\circledR}$ using different obturation techniques.

Study Design. Three hundred teeth, prepared with a crown-down technique, were divided into thirty experimental groups $(\mathrm{n}=10)$ to evaluate the apical and coronal leakage, at 3, 30 and 120 days, of lateral compaction gutta-percha + AH Plus ${ }^{\mathrm{TM}}$, lateral compaction gutta-percha + GuttaFlow ${ }^{\circledR}$, single cone + AH Plus ${ }^{\mathrm{TM}}$, single cone + GuttaFlow ${ }^{\circledR}$, and GuttaFlow ${ }^{\circledR}$ only.

Results. Both coronal and apical leakage, at the three times of measurement, no significant differences were found among GuttaFlow ${ }^{\circledR}+$ lateral compaction gutta-percha and GuttaFlow ${ }^{\circledR}+$ single cone groups, whereas the only GuttaFlow ${ }^{\circledR}$ reached the highest leakage values at 30 and 120 days. AH Plus ${ }^{\mathrm{TM}}$, using both techniques, showed high levels of leakage after 120 days to the coronal leakage and after 30 days to the apical leakage when compared silicon based sealer.

Conclusion. GuttaFlow ${ }^{\circledR}$, using with lateral compaction and single cone techniques, shows a greater apical and coronal sealing ability than AH Plus ${ }^{\mathrm{TM}}$ over time. GuttaFlow ${ }^{\circledR}$ when used as only creates a poorer sealing than when used with lateral compaction gutta-percha or single cone techniques.
\end{abstract}

Key words: AH Plus ${ }^{\mathrm{TM}}$, GuttaFlow ${ }^{\circledR}$, apical leakage, coronal leakage, lateral compaction, single cone. 


\section{Introduction}

Contemporary obturation techniques and filling materials do not completely seal the root canal system, and apical and coronal leakage may lead to failures of the rootcanal therapy (1). The root canal filling paste called GuttaFlow ${ }^{\circledR}$ (Colténe/Whaledent, Altstätten, Switzerland) is a modification of the RSA RoekoSeal Automix (Roeko Dental Products, Langenau, Germany). GuttaFlow ${ }^{\circledR}$ is a mixture of gutta-percha powder, poly-dimethylsiloxane and silver particles. Its capacity to expand slightly on setting (2) and its increased flowability (3) allow for good adaptation to the root canal walls and to the gutta-percha. Although it has a homogeneous composition, after setting it presents small porous areas (4). Radiographic quality is similar to other resin-based sealers such as Resilon/ Epiphany ${ }^{\circledR}$ and EndoRez ${ }^{\circledR}(5)$. Its low toxicity has been demonstrated and compared with that of different endodontic sealers including AH Plus ${ }^{\mathrm{TM}}$, Epiphany ${ }^{\circledR}$, EndoRez ${ }^{\circledR}$, RoekoSeal, Apexit ${ }^{\circledR}$ and Acroseal (6). Moreover, it is easy to remove from the interior of the canal, leaving fewer remains in the canal after retreatment than other materials, such as gutta-percha, TubliSeal ${ }^{\mathrm{TM}}$, EndoRez ${ }^{\circledR}$ and RealSeal' ${ }^{\mathrm{TM}}$ (7).

Studies evaluating sealing capacity have shown contradictory results when comparisons are drawn with different endodontic cement sealers. Ozok et al (8), in assessing the sealing capacity of GuttaFlow ${ }^{\circledR}$ and RoekoSeal, both with a modified single-cone technique, and $\mathrm{AH}$ $26{ }^{\circledR}$ with cold lateral compaction of the gutta-percha, obtained the highest values of glucose penetration with GuttaFlow ${ }^{\circledR}$ and the lowest ones with AH $26 \AA$. Kontakiotis et al. (9), using a fluid-transport model, report that the coronal leakage of the root canals filled with AH $26{ }^{\circledR}$ plus lateral compaction of gutta-percha or System B technique was significantly more than with GuttaFlow ${ }^{\circledR}$ at 12 months. Monticelli et al. (10), using the same methodology, found that GuttaFlow ${ }^{\circledR}$ and Activ GP with a single-cone technique provided inferior coronal seal than AH Plus ${ }^{\mathrm{TM}}$ with hot compaction of the gutta-percha. These authors recommended placement of accessory cones to reduce sealer thickness coronally. In terms of bacterial filtration, the apical sealing capacity of the AH Plus ${ }^{\mathrm{TM}} /$ System B was better than the Activ GP and GuttaFlow ${ }^{\circledR}$ sealants and the single-cone technique (11). Using cold lateral compaction, the silicone-based sealers (12) gave lesser saliva filtration values than did AH Plus ${ }^{\mathrm{TM}}$, after an observation period of nine weeks. The aim of the present study was to compare the apical and coronal filtration of canals obturated with GuttaFlow ${ }^{\circledR}$ as the only filling material, and canals obturated with GuttaFlow ${ }^{\circledR}$ and $\mathrm{AH}$ Plus ${ }^{\mathrm{TM}}$ using lateral condensation and single-cone techniques, at 3, 30 and 120 days.

The null hypothesis was that the sealing ability of GuttaFlow ${ }^{\circledR}$ used as the only filling material would be no different than GuttaFlow ${ }^{\circledR}$ used with cold lateral compaction or single-cone techniques at 3,30 and 120 days of storage. A secondary hypothesis was that there would be no differences in the ability of GuttaFlow ${ }^{\circledR}$ and $A H$ Plus ${ }^{\mathrm{TM}}$ to seal root canals when using either cold lateral compaction or the single-cone technique.

\section{Materials and Methods}

Three hundred and twenty extracted human singlerooted teeth with mature apices were used in this study. After removing traces of tartar, periodontal ligament or blood from the root surface with Gracey periodontal curettes No. 5/6 (HF-S65. Hu-Friedy, Leimen, Germany), the specimens were stored in $1 \%$ thymol solution at room temperature for less than 1 month. Before preparation, the teeth were rinsed under running water to eliminate the remains of this substance.

\section{- Sample preparation}

The crown of each tooth was cut to obtain root segments approximately $15 \mathrm{~mm}$ in length. Working lengths were determined by inserting a \#10 K-file (Dentsply Maillefer, Ballaigues, Switzerland) inside the root canal until it was visible at the apical foramen, then subtracting $1 \mathrm{~mm}$ from that length. The coronal half of the root canals was preflared using Gates Glidden drills (Dentsply Maillefer, Ballaigues, Switzerland) in a larger to smaller sequence (numbers 4-3-2); and the canals were copiously irrigated with $2.5 \%$ sodium hypochlorite solution using a 27-gauge endodontic needle (Monoject, Sherwood Medical, St. Louis, MO, USA). Middle and apical thirds were prepared sequentially to \#40 apical size, and they were alternately irrigated with $5 \mathrm{ml}$ of $2.5 \%$ sodium hypochlorite and $5 \mathrm{ml}$ of $25 \%$ citric acid after each change of file. The canals were dried with paper points (Roeko, Coltene/Whaledent, Langenau, Germany) and the patency of the apical foramen was confirmed with a \#10 K-file. The specimens were randomly divided into 3 experimental groups of 100 teeth each, according to the time period of storage of the specimens (3, 30 and 120 days), plus 10 positive and 10 negative control roots. Each set of 100 roots was divided into two groups of 50 roots to evaluate both apical and coronal leakage. Subsequently, 5 subgroups $(\mathrm{n}=10)$ were established as follows: 1) lateral compaction of gutta-percha + AH Plus ${ }^{\mathrm{TM}}$; 2) lateral compaction of gutta-percha + GuttaFlow ${ }^{\circledR} ; 3$ ) single cone + AH Plus ${ }^{\mathrm{TM}}$; 4) single cone + GuttaFlow ${ }^{\circledR}$; and 5) GuttaFlow ${ }^{\circledR}$ only. The composition of both sealers is showed in Table 1 .

\section{- Root canal filling}

Group cold lateral compaction of gutta-percha $+\mathrm{AH}$ Plus $^{\mathrm{TM}}$ (LGPAH). A standard size gutta-percha cone that matched the master apical file was fitted to the working length with tug back. AH Plus ${ }^{\mathrm{TM}}$ sealer was mixed according to the manufacturer's instructions. The master cone was coated with $\mathrm{AH}$ Plus ${ }^{\mathrm{TM}}$ and distributed 
Table 1. Composition of the materials.

\begin{tabular}{|c|c|}
\hline MATERIALS & COMPONENTS \\
\hline $\begin{array}{l}\text { AH Plus }{ }^{\mathrm{TM}} \\
\text { Dentsply/Maillefer, Konstanz, Germany }\end{array}$ & $\begin{array}{l}\text { Paste A(epoxy): } \\
\text { - Diglycidil-bisphenol-A-ether. } \\
\text { - Calcium. } \\
\text { - Tungsten. } \\
\text { - Zirconium oxide. } \\
\text { - Aerosol. } \\
\text { - Iron. } \\
\text { - Oxide. } \\
\text { Paste B (amina): } \\
\text { - Amina 1-adamantane. } \\
\text { - N, Ndibenzyl-5-oxanonandiamine-1, } 9 . \\
\text { - TCD-diamine. } \\
\text { - Calcium tungsten. } \\
\text { - Zirconium oxide. } \\
\text { - Silicone oxide. }\end{array}$ \\
\hline $\begin{array}{l}\text { GuttaFlow }{ }^{\circledR} \\
\text { Coltene-whaledent Langenau, Germany }\end{array}$ & $\begin{array}{l}\text { - Polydimethylsiloxane particles. } \\
\text { - Silicone. } \\
\text { - Paraffin oil. } \\
\text { - Platinum catalyst. } \\
\text { - Zirconium dioxide. } \\
\text { - Nano-silver. } \\
\text { - Gutta-percha powder. }\end{array}$ \\
\hline
\end{tabular}

with slight movements in the apico-coronal direction, and perfectly seated to the apical preparation. Lateral condensation was then carried out using size 20 accessory gutta-percha cones (Roeko, Coltene/Whaledent, Langenau, Germany) with endodontic finger spreaders placed within $1 \mathrm{~mm}$ of the working length. The guttapercha cones coated with sealer were laterally compacted until they could not be introduced more than $3 \mathrm{~mm}$ into the root canal. Excess gutta-percha was removed with a heated instrument.

Group cold lateral compaction of gutta-percha + GuttaFlow ${ }^{\circledR}$ (LGPGF). A \#40 gutta-percha cone was prefitted with tug-back, and a capsule of GuttaFlow ${ }^{\circledR}$ underwent trituration for $30 \mathrm{~s}$ in an amalgamator. GuttaFlow $\AA$ was placed on a mixing pad for coating master-cones. The prefitted master-cone coated with additional GuttaFlow ${ }^{\circledR}$ was introduced into the canal. Lateral compaction was then carried out using size 20 accessory gutta-percha cones with endodontic finger spreaders (Dentsply Maillefer, Ballaigues, Switzerland) placed within $1 \mathrm{~mm}$ of the working length. Excess gutta-percha was removed with a heated instrument.

Group single cone + AH Plus ${ }^{\mathrm{TM}}(\mathrm{SCAH})$. AH Plus ${ }^{\mathrm{TM}}$ was introduced into the canal space with a \#30 lentulo spiral at low speed and a distance of 3-4mm working length. The master cone was coated with sealer and placed at the working length. Excess gutta-percha was removed using a heated instrument.

Group single cone + GuttaFlow ${ }^{\circledR}$ (SCGF). The master cone was coated with the sealer and slowly inserted into the canal. Backfilling of the GuttaFlow ${ }^{\circledR}$ sealer was perfomed by inserting the special tip between the master cone and canal walls. Excess gutta-percha was removed with a heated instrument.

Group GuttaFlow ${ }^{\circledR}$ only (GF). GuttaFlow ${ }^{\circledR}$ was injected into the root canal by placing the delivery tip within $3 \mathrm{~mm}$ of the root apex. After filling the entire root canal with GuttaFlow ${ }^{\circledR}$, a \#15 file (Dentsply Maillefer, Ballaigues, Switzerland) was used to remove any air voids trapped in the root canal during the injection of GuttaFlow ${ }^{\circledR}$. Excess gutta-percha was removed with a heated instrument.

The test groups were kept at $37^{\circ} \mathrm{C}$ for 3,30 and 120 days, in $100 \%$ relative humidity. At the end of this period, the roots were covered with a layer of cianocrylate, and two layers of nail varnish were applied to all surfaces except the apical $2 \mathrm{~mm}$ for the teeth in the apical leakage testing group, and the coronal access in the coronal leakage testing group.

Group negative controls. After preparation of the teeth, the apical and coronal accesses were filled with an intermediate restorative material (IRM $\AA$ Dentsply, DeTrey, Germany). Then, a layer of cianocrilate plus two layers of nail varnish were applied on the entire tooth surface. Group positive controls. The teeth were filled only with gutta-percha cones. The entire surface of the tooth, except for $2 \mathrm{~mm}$ apical or coronal, was covered with a layer of cianocrilate and then two coats of nail varnish.

- Dye measurement

All teeth were immersed in a methylene blue $2 \%$ and 
stored at $37^{\circ} \mathrm{C}$ for $72 \mathrm{~h}$, after which they were thoroughly rinsed in running water. The nail varnish was removed with a scalpel blade. The teeth were longitudinally sectioned in a bucco-lingual direction using a microtome Accutom (Struers A/S, Ballerup, Denmark) to obtain two symmetrical halves.

The degree of microleakage was determined by measuring the linear extent of methylene blue penetration from the apical end of the preparation to the maximum extent in a coronal direction (apical leakage testing), and from the coronal limit to the maximum penetration in the apical direction (coronal leakage testing). To determine the most coronal (apical leakage testing) and apical (coronal leakage testing) point of linear leakage, two measurements were made: first, after splitting the roots, dye penetration was measured as dye visible on the filling material or on the canal walls; secondly, after the filling material was removed with an endodontic explorer, dye penetration was measured on the canal walls. The measurements of dye penetration were compared, the greater of the two selected as the definitive point of linear dye leakage (13).

To eliminate bias, apical and coronal leakage were measured independently by two evaluators, and the final values recorded were the arithmetic means of the measures obtained by the two. All measurements were obtained by means of a stereomicroscope (SZ-PT, Olympus, Japan) at $\times 20$ magnification with a calibrated ocular scale.

\section{- Statistical analysis}

First, a factorial regression model was used to assess the significance of the interaction between three factors (sealer cement, root canal filling technique and immersion time) for the coronal and the apical leakage data. Mean and standard deviations were determined for each group. The Shapiro-Wilk test was used to check normality of the data distribution. As the results for each group did not follow a normal distribution, the variables were analyzed using a nonparametric test. The coronal and apical ink leakage seen with the different sealer cement/root canal filling techniques in different immersion times was analyzed using the Mann-Whitney U-test (pairwise comparisons) and the Kruskal-Wallis test (global comparisons). The level of statistical significance was set at $\mathrm{P}<0.05$. All statistical analyses were performed by means of SPSS 15.0 software (SPSS Inc., Chicago, IL).

\section{Results}

Factorial regression analysis of the influence of the sealer cement (AH Plus ${ }^{\mathrm{TM}}$ or GuttaFlow $\left.{ }^{\circledR}\right)$, the root canal filling technique (cold lateral compaction, single-cone, or only sealer cement) and the time of immersion in ink $(3,30$, or 120 days) revealed statistically significant interaction for immersion time $\mathrm{x}$ sealer cement factors and time immersion $\mathrm{x}$ root canal filling technique factors, both in terms of coronal leakage $(\mathrm{p}<0.001$ and $\mathrm{p}<0.001$, respectively) and in apical leakage ( $\mathrm{p}=0.042$ and $\mathrm{p}=0.005$ ).

Tables 2 (coronal) and 3 (apical) show the leakage means for each type of sealer cement/root canal filling technique in different immersion times. Group LGPAH leaked more in coronal at 120 days; but in apical, leakage increased over time. Group SCAH showed leakage that was progressively greater over the three time periods, whereas group GF reached its highest leakage, both coronal and apical, at 30 days. Groups LGPGF and SCGF exhibited very limited variation in leakage (mean values) over the three time periods.

In coronal, after three days, the teeth filled with only GuttaFlow ${ }^{\circledR}$ exhibited the lowest mean leakage (1.85), a result that differed significantly from that of groups LGPAH (2.93, $\mathrm{p}=0.028)$ and LGPGF $(2.75, \mathrm{p}=0.012)$. After 30 days, leakage mean values of the groups LGPAH (2.62), LGPGF (2.68), and group SCGF (2.92) were significantly lower than that of GF $(4.52)(\mathrm{p}=0.001$,

Table 2. Results of coronal leakage at three time periods (mean \pm standard deviation in millimetres).

\begin{tabular}{|c|c|c|c|}
\hline & 3 days & 30 days & 120 days \\
\hline \multicolumn{4}{|l|}{$\mathrm{AH}^{\mathrm{Plu}}{ }^{\mathrm{TM}}$} \\
\hline Cold lateral condensation & $2.93 \pm 1.16^{\mathrm{a}, 1}$ & $2.62 \pm 0.98^{\mathrm{b}, 1,2}$ & $4.60 \pm 0.41^{a, b, 1,2}$ \\
\hline Single cone & $2.47 \pm 0.73^{\mathrm{a}, \mathrm{b}}$ & $3.73 \pm 1.45^{\mathrm{a}, 1}$ & $4.61 \pm 0.60^{\mathrm{b}, 3,4}$ \\
\hline \multicolumn{4}{|l|}{ GuttaFlow $^{\mathrm{TM}}$} \\
\hline Cold lateral condensation & $2.75 \pm 0.76^{2}$ & $2.68 \pm 1.23^{3}$ & $2.77 \pm 0.49^{1,3,5}$ \\
\hline Single cone & $2.25 \pm 0.87^{a}$ & $2.92 \pm 0.68^{\mathrm{a}, 4}$ & $2.47 \pm 0.73^{2,4,6}$ \\
\hline Only cement sealer & $1.85 \pm 0.59^{a, b, 1,2}$ & $4.52 \pm 0.40^{a, 2,3,4}$ & $4.51 \pm 0.81^{\mathrm{b}, 5,6}$ \\
\hline
\end{tabular}

*In the factorial regression model, $P$ values were $<0.001$ (for immersion time sealer cement interaction) and $<0.001$ (for time immersion root canal filling technique interaction).

Read horizontally, the same letters indicate presence of significant differences.

Read vertically, the same numbers indicate presence of significant differences. 
Table 3. Results of apical leakage at three time periods (mean \pm standard deviation in millimetres).

\begin{tabular}{llcc}
\hline & \multicolumn{1}{c}{3 days } & 30 days & 120 days \\
\hline AH Plus & & & \\
$\quad$ Cold lateral condensation & $2.27 \pm 0.73^{\mathrm{a}, 1}$ & $3.07 \pm 1.09^{1,2,3}$ & $3.41 \pm 1.13^{\mathrm{a}, 1,2}$ \\
$\quad$ Single cone & $1.39 \pm 0.80^{\mathrm{a}, \mathrm{b}, 1}$ & $3.28 \pm 0.94^{\mathrm{a}, 4, \mathrm{~b}}$ & $3.88 \pm 0.80^{\mathrm{b}, 3,4}$ \\
GuttaFlow & & & \\
$\quad$ Cold lateral condensation & $1.38 \pm 1.23$ & $2.10 \pm 0.60^{1,4,6}$ & $2.22 \pm 0.54^{1,3,5}$ \\
$\quad$ Single cone & $1.44 \pm 1.05^{\mathrm{a}}$ & $2.10 \pm 0.59^{2,5,7}$ & $2.19 \pm 0.39^{\mathrm{a}, 2,4,6}$ \\
$\quad$ Only cement sealer & $1.89 \pm 1.01^{\mathrm{a}, \mathrm{b}}$ & $4.15 \pm 1.33^{\mathrm{a}, 3, \mathrm{~b}, \mathrm{l}}$ & $4.19 \pm 0.89^{\mathrm{b}, \mathrm{b}, \mathrm{b}}$ \\
\hline
\end{tabular}

* In the factorial regression model, $P$ values were 0.042 (for immersion time sealer cement interaction) and 0.005 (for time immersion root canal filling technique interaction). Read horizontally, the same letters indicate presence of significant differences. Read vertically, the same numbers indicate presence of significant differences.

$\mathrm{p}=0.001$ and $\mathrm{p}<0.001$, respectively). At 120 days, groups LGPGF (2.77) and SCGF (2.47) leaked significantly less than the other three groups $(\mathrm{p}<0.001)$.

In apical, after three days, only the comparison between group LGPAH (2.27) and group SCAH (1.39) showed statistically significant differences $(\mathrm{p}=0,021)$. At 30 and 120 days, however, the group GF (4.15 and 4.19) showed significant differences from group LGPGF $(p=0.001$ and $\mathrm{p}<0.001)$ and group SCGF $(\mathrm{p}<0.001)$.

\section{Discussion}

The sealing ability of a root canal filling material is an important factor in preventing leakage of microorganisms and reinfection of the root canal system. In this way, the importance of smear layer removal to improve the resistance of filled canals to bacterial leakage from a coronal or apical direction has been showed. The combined use of $25 \%$ citric acid and $2.5 \% \mathrm{NaOCl}$ during instrumentation of root canals is an effective method for removing the smear layer from the canal walls and dentinal tubules (14). In addition a final rinse with distilled water is recommended in order to minimize the compromising effect of $\mathrm{NaOCl}$ on primer/resin-sealer polymerization (15).

Lateral compaction was the technique of choice for this study because it is very widely used and facilitates comparison with previous studies (12). The passive diffusion evaluation of tracers is the simplest and most commonly used technique to evaluate the sealing ability of root canal fillings and the longitudinal splitting of the root combined with dye penetration enhances demonstration of the pattern of dye penetration (13).

Among the new techniques for preparation of the root canal, as well as new materials for root sealing, the single-cone method or the application of sealer as the only filling material are increasingly recommended proce- dures $(9-11,16,17)$. GuttaFlow ${ }^{\circledR}$ has been studied in sole use to fill the root canal (18), in cold lateral compaction (12) or with just a single gutta-percha cone $(9,18)$, as recommended by the manufacturer.

In this study, none of the sealers or techniques applied proved capable of avoiding apical and coronal filtration in root canals filled. The sealing capacity of GuttaFlow ${ }^{\circledR}$ was similar in conjunction with lateral condensation or the single-cone technique, showing no statistically significant differences. With cold lateral compaction, GuttaFlow ${ }^{\circledR}$ again gave similar results in the time periods studied here. De-Deus et al. (12) showed that siliconebased sealers (GuttaFlow ${ }^{\circledR}$ and RoekoSeal) appeared to remain stable in terms of bacterial contamination after the third week.

GuttaFlow ${ }^{\circledR}$ used as the only filling material resulted in more filtration, both coronal and apical, after 30 and 120 days. These findings might be attributed to the greater amount of sealer used in this group. A high frequency of the voids at all measurement levels in the GuttaFlow ${ }^{\circledR}$ group, although smaller in area, could increase the possibility of communication between these voids and the apical and coronal ends of the root canal filling (4). Our working hypothesis must therefore be refuted: the sealing ability of GuttaFlow ${ }^{\circledR}$ when used as the only filling material was indeed different from GuttaFlow ${ }^{\circledR}$ used with cold lateral compaction or single-cone techniques at 3,30 and 120 days of storage.

The second hypothesis behind our study must also be rejected, as there were differences in the ability of GuttaFlow ${ }^{\circledR}$ and $\mathrm{AH}$ Plus ${ }^{\mathrm{TM}}$ to seal root canals when using cold lateral compaction or single-cone techniques. According to our results, $\mathrm{AH}$ Plus ${ }^{\mathrm{TM}}$ would allow more coronal filtration than GuttaFlow ${ }^{\circledR}$ at 120 days' time, with either lateral condensation or single-cone as the technique applied. In terms of apical filtration, the AH 
Plus $^{\mathrm{TM}}$ sealer also presented greater filtration than GuttaFlow ${ }^{\circledR}$ in conjunction with both these techniques at 30 days. The good adaptation to the root canal walls and to the gutta-percha of GuttaFlow ${ }^{\circledR}$ could be attributed to its capacity to expand slightly on setting (2).

The results of our study come to support those of previous authors, despite methodological variations. DeDeus et al. (12), using lateral condensation, found that silicone-based sealers (GuttaFlow ${ }^{\circledR}$ and RoekoSeal) resulted in a lesser number of samples contaminated by human saliva than AH Plus ${ }^{\mathrm{TM}}$ or Pulp Canal Sealer after 9 weeks of storage. Edelniz et al. (19) evaluated the resistance to bacterial penetration of different sealers with the single-cone technique, finding that GuttaFlow ${ }^{\circledR}$, Epiphany ${ }^{\circledR}$ and Apexit ${ }^{\circledR}$ were more effective than AH Plus ${ }^{\mathrm{TM}}$, RoekoSeal, RCS, EndoRez ${ }^{\circledR}$ and Acroseal. Meanwhile, Bouillaguet et al. (20) carried out a long-term comparison of the apical sealing capacity of different sealers in conjunction with the single-cone technique, reporting better results using GuttaFlow ${ }^{\circledR}$ and Epiphany ${ }^{\circledR}$ than with PCS and AH Plus ${ }^{\mathrm{TM}}$; according to these authors, the leakage of AH-Plus ${ }^{\mathrm{TM}}$ may have resulted from inadequate bonding between the sealer and the gutta-percha point, allowing fluid to flow at the interface. However, the epoxy resin-based sealers have shown better adhesion to the root dentin that others groups of sealers. The epoxy resin-based sealer, like $\mathrm{AH} 26$ or AH Plus ${ }^{\mathrm{TM}}$, is thought to be able to react with any exposed amino groups in collagen to form covalent bonds between the resin and collagen when the epoxide ring opens.

Under the conditions of this ex vivo evaluation, we may conclude that GuttaFlow ${ }^{\circledR}$, over time, shows a greater apical and coronal sealing capacity than AH Plus ${ }^{\mathrm{TM}}$. The lowest ability to prevent filtration in the obturation of root canals was obtained by applying GuttaFlow ${ }^{\circledR}$ as the only sealing material.

\section{References}

1. De Moor R, Hommez G. [The importance of apical and coronal leakage in the success or failure of endodontic treatment]. Rev Belge Med Dent. 2000;55:334-44.

2. Hammad M, Qualtrough A, Silikas N. Extended setting shrinkage behavior of endodontic sealers. J Endod. 2008;34:90-3.

3. Zielinski TM, Baumgartner JC, Marshall JG. An evaluation of Guttaflow and gutta-percha in the filling of lateral grooves and depressions. J Endod. 2008;34:295-8.

4. Elayouti A, Achleithner C, Löst C, Weiger R. Homogeneity and adaptation of a new gutta-percha paste to root canal walls. J Endod. 2005;31:687-90.

5. Herbert J, Bruder M, Braunsteiner J, Altenburger MJ, Wrbas KT. Apical quality and adaptation of Resilon, EndoREZ, and Guttaflow root canal fillings in combination with a noncompaction technique. J Endod. 2009;35:261-4.

6. Eldeniz AU, Mustafa K, Ørstavik D, Dahl JE. Cytotoxicity of new resin-calcium hydroxide- and silicone-based root canal sealers on fibroblasts derived from human gingiva and L929 cell lines. Int Endod J. 2007;40:329-37.
7. Hammad M, Qualtrough A, Silikas N. Three-dimensional evaluation of effectiveness of hand and rotary instrumentation for retreatment of canals filled with different materials. J Endod. 2008;34:1370-3

8. Ozok AR, van der Sluis LW, Wu MK, Wesselink PR. Sealing ability of a new polydimethylsiloxane-based root canal filling material. J Endod. 2008;34:204-7.

9. Kontakiotis EG, Tzanetakis GN, Loizides AL. A 12-month longitudinal in vitro leakage study on a new silicon-based root canal filling material (Gutta-Flow). Oral Surg Oral Med Oral Pathol Oral Radiol Endod. 2007;103:854-9.

10. Monticelli F, Sword J, Martin RL, Schuster GS, Weller RN, Ferrari $\mathrm{M}$, et al. Sealing properties of two contemporary single-cone obturation systems. Int Endod J. 2007;40:374-85.

11. Monticelli F, Sadek FT, Schuster GS, Volkmann KR, Looney SW, Ferrari M, et al. Efficacy of two contemporary single-cone filling techniques in preventing bacterial leakage. J Endod. 2007;33:310-3. 12. De-Deus G, Brandão MC, Fidel RA, Fidel SR. The sealing ability of GuttaFlow in oval-shaped canals: an ex vivo study using a polymicrobial leakage model. Int Endod J. 2007;40:794-9.

13. De Moor RJ, Hommez GM. The long-term sealing ability of an epoxy resin root canal sealer used with five gutta percha obturation techniques. Int Endod J. 2002;35:275-82.

14. Pérez-Heredia M, Ferrer-Luque CM, González-Rodríguez MP. The effectiveness of different acid irrigating solutions in root canal cleaning after hand and rotary instrumentation. J Endod. 2006;32:993-7.

15. Lai SC, Mak YF, Cheung GS, Osorio R, Toledano M, Carvalho RM, et al, Reversal of compromised bonding to oxidized etched dentin. J Dent Res. 2001;80:1919-24.

16. Whitworth JM, Baco L. Coronal leakage of sealer-only backfill: an in vitro evaluation. J Endod. 2005;31:280-2.

17. Wu MK, van der Sluis LW, Wesselink PR. A 1-year follow-up study on leakage of single-cone fillings with RoekoRSA sealer. Oral Surg Oral Med Oral Pathol Oral Radiol Endod. 2006;101:662-7.

18. Brackett MG, Martin R, Sword J, Oxford C, Rueggeberg FA, Tay FR, et al. Comparison of seal after obturation techniques using a polydimethylsiloxane-based root canal sealer. J Endod. 2006;32:1188-90.

19. Eldeniz AU, Ørstavik D. A laboratory assessment of coronal bacterial leakage in root canals filled with new and conventional sealers. Int Endod J. 2009;42:303-12.

20. Bouillaguet S, Shaw L, Barthelemy J, Krejci I, Wataha JC. Longterm sealing ability of Pulp Canal Sealer, AH-Plus, GuttaFlow and Epiphany. Int Endod J. 2008;41:219-26. 